\title{
LCP1/BCL6 Fusion Gene
}

National Cancer Institute

\section{Source}

National Cancer Institute. LCP1/BCL6 Fusion Gene. NCI Thesaurus. Code C99189.

A fusion gene that results from a chromosomal translocation $t(3 ; 13)(q 27 ; q 14)$ which fuses the promoter region of the LCP1 gene near the 5 ' end of the BCL6 gene. This rearrangement is associated with aberrant expression of the BCL6 gene product and non-Hodgkin follicular lymphoma and Burkitt lymphoma. 